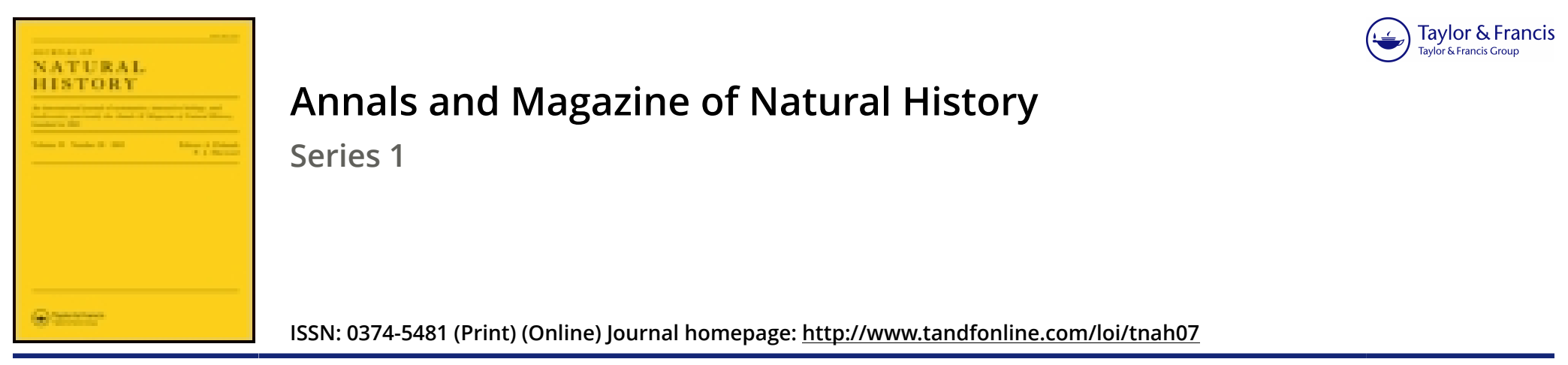

\title{
XXXIV.-Observations on the Progress recently made in the Natural History of the Echinodermata
}

\section{Prof. Agassiz}

To cite this article: Prof. Agassiz (1842) XXXIV.-Observations on the Progress recently made in the Natural History of the Echinodermata, Annals and Magazine of Natural History, 9:58, 296-302, DOI: $10.1080 / 03745484209445340$

To link to this article: http://dx.doi.org/10.1080/03745484209445340

\section{曲 Published online: 04 Dec 2009.}

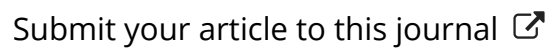

Џ Article views: 1 
wards beings more and more complicated, arrive at the very summit of the series, viz. Amanita casarea.

'The various developments which the unfolding of this new subject for contemplation would allow of, would carry me beyond my object. Far from having exhausted, I have, alas! scarcely glanced over it. I leare this to those who are more capable. I could attempt only a feeble sketch; may it at least be sufficient to guide the reader in the milst of the numerous difficulties which await him in the study of this great and important class of the vergetable kingdom.

Paris, F'eb. 1, 1811.

XXXIV.-Observations on the Progress recently made in the Nutural History of the Echinodermata. By Prof. Agassiz.

[Continued from p. 197.]

In my 'Prodromus' I expressed doubts as to the membranous ambulacral tubes in the Sea-urchins having any relation to their powers of locomotion, grounding my opinion upon some observations which I had made on the sandy shores of Normandy, and upon the very positive assertion of Aristotle, who tells us that they move by the aid of their spines; and that cren by the state of these organs their degrec of progressive power may be known (liv. iv. chap.v.). Mr. Forbes, however, has shown this view of the matter to be crroneous, and has demonstrated that they also progress by means of their ambulacral tubes, especially when upon solid surfaces. In complany with this gentleman I have seen them ascend, by the aid of these tubes, the perpendicular sides of a smooth glass vessel. No further evidence could be ranted to set at rest the point in question. It yet remains to be shown whether, among the Cidcerites, the long club-shaped spincs are not the principal organs of motion, and that it is among the Sea-urchins with very short bristles that the ambulacral tubes are essential to this function. M. de Siebold mentions the cxistence of microscopic cilia in the interior of these tentacula and of thcir vesicles (Mül. Archiv, 1836, p. 295). M. Ehrenberg, on the other hand, describes the vibratory movements in the membrane of the spines of Eclinus saxatilis (movements which are denied by Mr. Forbes), and indicates the existence of an internal circulation of corpuscles, similar to the globules of blood, in the retractile tentacula upon the dorsal face of the Asterias violacea; he adds, morcover, that the surface of these tentacula is entirely covered with vibratile cilia (Mül. Archiv, 1834, p. 577). M. Volkmann has also given some new details upon the circulation in the Asterice, 
but I am only acquainted with his researches from extracts (Wiegm. Archiv, 1838, vol. ii. p. 333).

The history of the development of the Echinodermata is enriched with many important facts. M. Sars has made known the changes which the Asterias sanyuinolenta of Müller undergoes during the carly stages of its existence.

Mr. Thompson of Cork, trrelve years after having described his Pentacrinus europecus, published a second memoir on this animal, in which he regards it as the young state of the Comatula rosacea. 'This opinion has becn fully confirmed by' Messrs. Forbes, 'Thompson of Belfast, and l3all, who have seen the living Pentacrinus europecus detach itself from its stalk, and swim freely in the form of a small Comatula. 'The information given by MIr. Forbẹs regarding the development of this Comatula is highly curious.

M. de Sicbold has indicated the existence of the resicle and the germinal spot in all the Asterice which he examined (Müll. Archiv, 1836, p. 297). M. J. Müller has also described the vesicle and germinal spot of the Comatule and Oplizera. M. Peters (Miull. Archiv, 1840, p. 143) announces that the Sen-urchins have the sexes distinct. 'They do not differ externally it is true; the sexual organs in both males and females have the same appenrance; but in the females of Echinus purpureus and E. MIflo the sexual glands are red, and contain ova where the vitellus and germinal vesicle are to be distinguished, whilst in the males these are white, and only filled with spermatozoa. MM. Valentin and R. Wagner have likewise noticed a distinction of sexes amongst the Holothurie, and M. Rathke among the Asteria. M. J. Müller, moreover, observes that it is probably the same in the Crinoidece, or at least in the Comaluke (Müll. Archiv, 1840, 1.144). MM. Valentin and Miescher have observed spermatozon in the Spatangus purpureus (Repert. de Valentin, 1840, p. 301). M. Milne Edwards has confirmed these facts by additional obscrvations.

In a special memoir inserted in Wiegm. Archiv. for 1837 (vol. i. p. 241), M. Philippi has described two monstrosities in the genera Echinus and Spatanyus. MMI. H. de Meyer and Agassiz have also made known various monstrosities depending both upon deficiency and excess.

Many lengtlyy memoirs have appeared upon the fossil Echinodermata, and a large number of species 1 ill be found described in a variety of general works upon geology and paleontology. But these works are wanting still in agrecment, most of the authors differing in opinion as to the limits which should be assigned to genera. The genera which have been Ann.\& Mag. N. Hist. Vol. ix. 
established subsequently to those of Miller among the Crinoidea, and which are very numerous, would appear especially to call for revision. M. Alcide d'Orbigny has just undertaken this difficult task, in publishing his ' Histoire naturelle des Crinoïles vivans et fossiles,' a work which is based upon the critical examination of a very extensive collection of specimens. It appears to me that the great merit of this monograph consists in the systematic arrangement of the genera, which are here distributed into natural families, whilst before we had them disposed without any method, but just as some might happen to follow upon others (pếle-mếle ì la suite les ans des autres). Three parts of this interesting work have already appeared, which contain descriptions of the genera Guettardicrinus, Apiocrinus, and Millericrinus, of the family Apiocrinoidece. It is only to be rerretted that M. d'Orbigny was not aware of the labours of MI. Ch. Künig, who, in his 'Icones sectiles,' had long since established many genera, of which his Ceriocrinus, Pomotocrinus, and Symphytocrinus appear to me synonymous with those proposed by M. d'Orbigny. M. L. de Buch has also published, in the Bulletins of the Berlin Academy, a critical investigation of the Spluesronites, a group of Crinoidece but little known, and whose structure had escaped the observation of his predecessors. 'This memoir is accompanied with beautiful figures. Jander has also given, in his ' Beytrïge zur Geognosie des Russischen Reichs,' some information upon these fossils, accompanied with figures. Count Munster, in a special memoir upon the fossil Crinoidea, inserted in the "Acta nova Academ. Cessar. Lcop. Carol. Nature Curiosorum,' t. xix. \&c., has made known a new genus under the name Gasterocoma, and has given excellent figures and admirnble descriptions of a large number of specics which had not been published in his great work on the fossils of Germany. In his 'Beyträge zur Petrefactenkunde,' Count Munster has also described many new Crinoidece of the transition period, among which are three new genera very remarkable for the disposition of the parts of the cup (calice), which, deviating from the quinary type so general in this group of animals, present numbers not found in the class Echinodermata. Ife calls these genera Diocrinus, Triacrinus, and Asterocrimus. Count Munster has moreover, in the same work, established his genus Comaturella, and described many new species belonging to known genera. $\mathrm{M}$. Herm. de Meyer has also established tro new genera of $\mathrm{Cr} i$ noidec in the 'Muscum Scnkenberginnum' for 1837, under the names Isocrinus and Chelocrinus. M. Bromn has described the genus Ctenocrinus in the 'Jahrbuch für Mineral. u. Petref.? 
for 1840; M. Steininger that of Halocrinites, in the eighth and ninth rolumes of the Bulletin of the Geological Society of France, and in the first volume of the Transactions of this Socicty. MM. Quenstedt (Wiegm. Archiv, 1835) and Bronu (Jahrb. für Min. 1837) have described some new species of Encrinus from the muschellalk; so that three species of this remarkable genus are now known.

$M r$. Phillips, in the second part of his 'Geology of Yorkshire,' besides describing many new species belonging to known genera, has established two new genera of Crinoidew from the conl-mensures, to which he gives the names Euryocrinus and Gillertsocrinus. The same writer has moreover described a great number of new Crinoidec belongring to the most ancient fossiliferous deposits, in the work of Mr. Murchison upon the Silurian system, among which we likewise find many new genera, which he calls MTarsupiocrinites, Hypanthocrinites, and Dimerocrinites. 'The genus Ischadites of M. König (Murch. Sil. Sys., pl. 26, fig. 11) also belongs to the Crinoidede; M. de Buch considers it to be identical with Sphceronites aurantium. Under the name Scyphocrinites, M. Zenker has described a peculiar form in this class, in his 'Naturgeschichte der Urwelt.' Lastly, MI. de Hagenow has made known a new genus allied to Solanocrinus, which he names Hertha, and many new species of Crinoidece and Echinide.

I shall allude again to the genera Glenotrentites of Goldfuss and Ganymed $a$ of Gray, because I have ascertained with certainty that they have been cstablished upon crinoidal axes belonging to the family of the Comatula, and consequently they ought to be suppressed. As regards the genera $\mathrm{Ca}$ ryocrinites, Say, and Trianisites, Rafinesque, these are only known to me by name. The genus Mar'supites of Mr. Mantell (Marsupium, König) is too well known to be mentioned as a recent acquisition to the science of palocontologs.

M. Römer, in his work upon the Jurassic fossils of the north of Germany, and in his sccond work upon the cretaccous fossils of the same country, describes a considerable number of new species amongst the Echinites and Crinoidece. MII. Koch and Dunker have described many new Echinites in the Supplement to the first work, and M. Hinsinger those of the formations in Srreden in his 'Lethas Succica,' accompanied with excellent figures.

The family of the Crinoidece ought especially to engage the attention of naturalists, inasmuch as, from the great variety of forms which it contains, it will furnish the clue to the development of the entire class Echinodermata. These forms are $\mathrm{X} 2$ 
as it were the precursors of the Comatule, the Asteria, and the Eclinites, the forms of which they have in some instances already appropriated. In this particular the most remarkable of all the genera is that which I shall describe under the name Echinocrinus, and which presents the perfectly spheroidal shape of the Sea-urchins, with the narrow ambulacra and long prickly spines of certain Cidarites. 'Ihe analogy with these last is so striking, that detached fragments of this genus. (which is only found in the conl-measures and transition formations) have already actually been clescribed as fiagments of Cidlarites. Such for instance, among others, are the Cidlaris Urii of Fleming, the Cidarites Nerei, Protci and priscus of Count Munster, and some other unpublished species.

But little is known at present of the fossil Asterice and Oplizere; a rery small number only have been described, amongst which, as new species, I shall mention those which Mr. Williamson has published in Loudon's 'Magazine of Natural History' for 1836, and those from the collections of the Earl of Enniskillen and Sir Philip Egerton, described by Mr. Broderip in the fifth volume of the "T'ransactions of the Gcological Socicty of London,' without enumernting those which have been published by Count Munster, M. Goldifuss, M. Des Moulins and M. Agassiz. Their number however is very considerable, and $\mathrm{I}$ am glad to amnounce a work by $\mathrm{Mr}$. Dixon which is to embrice all the British species.

M. Frédéric Dubois of Montpcreux, in the Atlas of his travels in the Crimea, \&c., has commenced the publication of the magnificent collection of fossils brought by him fiom those countrics by the issue of a large plate of lighly interesting Echinites. In the fourth volume of the second series of the 'Memoirs of the Academy of Sciences of 'Turin', De Sismonda has published a complete monograph of the fossil Echinites of Piedmont, in which he describes a new genus under the name Anaster, and a large number of new species accompanied with good figures. M. Grateloup has likewise published a special memoir upon the fossil Sea-urchins which occur in the calcareous formations in the environs of Dax (Actes de la Soc. Lin. de Bordeaux, tom. viii.). M. Leymeric has described many interesting species of the genus Diadcma in the third rol. of the 'Geol. Trans. of France.' In the same work, vol. ii, M. Dujardin has also described a new Seaurchin, from the chalk. M. de France has given, in the 'Dictionary of Natural Sciences' of Lerrault, numerous articles on the various genern of fossil Echinodermata, which make us acquainted with the condition of the science upon this 
subject at the period of the publication of this encyclopredia. Notwithstanding that it cmbraces these fossils in their totality, the great work of Goldfuss on the Petrifactions of Germany will for a long time to come be a standard work for the study of fossil Echinodernata.

In the 'Nouveaux Mémoires de la Soc. Helvétique des Scien. Naturelles' (tom. ii. et iv.), I have made known the fossil Echinites of Switzerland ; my descriptions are accompanied with figures which represent all the species under various aspects. In this memoir I have established the following genera :-Hyboclypus, Pygorhlynchus, Conoclypus, Pyguruis, Hemicidaris, Acrocidaris, Acrosalenia, Tetratgramme, Pedina, and Glypticus. In the first rolume of the "MIćm. de la Soc. des Sc. Nat. de Neuchittel,' I had previously published, in part, a notice on the species of the Neocomian formations; since then, in my systematic cataloguc of the casts of the fossil Sea-urchins in the museum at Neuchîtel *, I published the essential characters of the new or little known generia which I have established up to the present time anongst the Echinites. The following gencra are there characterized for the first time:-Toxastcr, Brissopsis, Nucleopygus, Globalor, Caratonus, Amblypygus, Ibeliophora†, Amphiope, Encope, Echinopsis, Cyphosonel, Acropeltis, Ccolopleurus, Codiopsis, Podlophora, and Acrocladia. The distribution of many serics of these casts has given a publicity to my researches upon the Echinites, which I hope will aid in advancing our knowledge of these fossils, and facilitate the identification of specimens which as yet may not be figured or even described. I have also put into circulation representations, as fuithful as it was possiblc to obtain then, of a great number of unique specimens in a rery perfect state of preservation.

Since the publication, in 1838, of my first monograph upon the Echinodermata, the matcrials at my disposal have been greatly augmented. A number of new species in all the orders of the class Echinodermata have been entrusted to me by the numcrous friends of science, who have considered that a most efficacious way of serving it would be that of bringing together, in the same publication, the greatest possible amount of data. I therefore esteem it both is duty and pleasure to rccord here the names of all those who have acruired new claims to my gratitude, whether it be in the communication

- Catalogus System. Ectyporum Eichinodermatun l'ossilium Musci Neocomensis, $410,1810$.

t 'This genus has since regaincd the name Rotula, given to it more than a century ago by Klein, but of which no o:e had taken notice. 
of original specimens, or in furnishing me with information upon the distribution or location of species. *** $*$

[The length to which the list extends of British and Foreign Naturalists to whom Prof. Agassiz expresscs his obligations, jrecludes our giving it insertion.-EDIT.]

Nenchâtel, July 1811.

XXXV.-Descriptions of ncw species of Coleopterous Insects belonging to the Gemus A pocyrtus, collected by Hugh Cuming, Esq., in the Philippine Islands. By G. R. W Esq., Assistant Secretary and Curator to the Zoological Socicty.

Order COLEOPTERA. Scct. CURCULIONIDES.

Div. PAchyrmyschides, Schö.

Genus Apocyrrus, Erichson.

Apocyrtus Schconherri.

Ap. niger; capitc notâ inter oculos et utrinque infra oculos; thorace notà transversâ anticâ, maculisque duabus lateralibus ct superioribus, necnon clytris maculis viginti-duabus, splendide cuprcis, vel aurco-cuprcis; rostro rugoso-punctato ad basin transversim impresso, capite et rostro canaliculo longitudinali impressis; thorace crebrè punctato; elytris globoso-ovatis ferè duplò thorace latioribus, distinctè punctatis, punctis jn striis irreglnlaribus dispositis. Long. corp. $8 \frac{1}{2}$ lin.; lat. $3 \frac{3}{5}$ lin.

This is the largest species of the genus I am acquainted with; its clytra are less globose, and the thorax is larger in proportion to the elytra than in Ap. inflatus : the beautiful metallic spots with which it is adorned vary somewhat in huc, being in some specimens of a reddish golden tint, and in others of a copper colour. 'The rostrum is thickly punctured, and the punctures are more or less confluent; $a$ transverse indented line separates the rostrum from the head, and a longitudinal impression runs from this line towards the fore-part of the rostrum, becoming gradually broader in front and terminating in a line with the insertion of the antennx. The head is rather sparingly punctured; between the eyes is a small metallic spot (in some specimens wanting), and beneath the cye is an oblique mark formed of brilliant scales. The thorax is very nearly equal in length and breadth, subglobose, and truncated before and behind; on the anterior margin is a transverse mark, about midway between the antetcrior and postcrior margins; and towards the side of the thorax is a round spot, and just above the insertion of the femur is a broad oblong mark formed of brilliant scales; the surface of the thorax is rather coarsely punctured, and the punctures are many of them confluent. The elytra are more than one-third broader than the thorax -sometimes ncarly twice as broad-about one-third broader than long, ovate and very conrex; they are punctured, and the punctures 